\title{
Bireysel Banka Müşterilerinin Hizmet Kalitesi Algılarının Müşteri Sadakati Üzerine Etkisi
}

\section{The Effect of Service Quality Perceptions of Individual Bank Customers on the Customer Loyalty}

\author{
Yusuf Öcel, ${ }^{\mathrm{a}, *}$ Nesrin Şen ${ }^{\mathrm{b}}$ \\ ${ }^{a}$ Dr. Öğr. Üyesi, Düzce Üniversitesi, İşletme Fakültesi, İşletme Bölümü, Düzce/Türkiye. \\ ORCID: 0000-0002-4555-7035

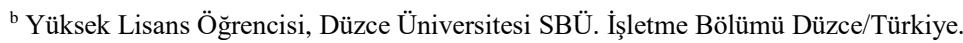 \\ ORCID: 0000-0002-5698-0613
}

\section{MAKALE BİLGISII}

\section{Makale Geçmişi :}

Başvuru tarihi: 05 Şubat 2019

Düzeltme tarihi: 01 Eylül 2019

Kabul tarihi: 05 Eylül 2019

\section{Anahtar Kelimeler:}

Bireysel Banka Müşterileri

Hizmet Kalitesi

Müşteri Sadakati

\section{ARTICLE INFO}

Article history:

Received 05 February 2019

Received in revised form 01 September 2019

Accepted 05 September 2019

\section{Keywords:}

Individual Bank Customers

Service Quality

Customer Loyalty
ÖZ

$\mathrm{Bu}$ araştırmanın amacı; bireysel banka müşterilerinin hizmet kalitesi algılarının müşteri sadakati üzerine etkisinin olup olmadığını incelemektir. İlk olarak literatür de algılanan hizmet kalitesiyle ilgili çalışmalar incelenmiştir. Daha sonra literatür de geliştirilen SERVPERF ölçeğinden yararlanılarak bireysel banka müşterilerinin hizmet kalitesiyle ilgili algıları ortaya çıkarılmıştır. Bu kapsamda araştırmanın evrenini Düzce il merkezinde ikamet eden 18 yaş üstü bireysel banka müşterileri oluşturmaktadır. $\mathrm{Bu}$ doğrultuda 384 kişiden anket tekniği kullanılarak veriler toplanmıştır. Elde edilen veriler SPSS hazır paket program kullanılarak analiz edilmiştir. Elde edilen verilere açıklayıcı faktör analizi, korelasyon analizi, çoklu doğrusal regresyon analizi, T-testi ve ANOVA testleri uygulanmıștır. Yapılan analizler sonucunda, algılanan hizmet kalitesi ile ilgili dört boyut, müşteri sadakati ile ilgili iki boyut ortaya çıkmıştır. Algılanan hizmet kalitesi ile ilgili boyutlar; güvenilirlik, fiziksel görünüm, isteklilik ve empatidir. Müşteri sadakati ilgili yapılan faktör analizinde ortaya çıkan boyutlar; davranışsal sadakat ve bilişsel sadakattir. Yapılan çoklu doğrusal regresyon analizi sonuçlarına göre algılanan hizmet kalitesi boyutlarının (güvenirlilik, heveslilik, empati, fiziksel görünüm) müşteri sadakatini (davranışsal sadakati ve bilişsel sadakati) etkilediği ortaya çıkmıştır. Katılımcıların özellikleri ile ilgili yapılan farklılık analizlerinde de anlamlı sonuçlar ortaya çıkmıştır.

\section{A B S T R AC T}

The aim of this study is to determine the effect of bank customers' perceived service on customer loyalty. For this purpose, at first the researches on perceived bank service were reviewed. Afterwards, service quality perceptions of bank service were determined by using SERVPERF scale that were developed in literature previously. In this context, The universe of the research is composed of individual bank customers over 18 years of age living in Duzce. Accordingly, data was gathered from 384 participants by questionnaire. Obtained data was analyzed using SPSS ready program. Descriptive factor analysis, multiple linear regression analysis, correlation analysis, $\mathrm{T}$ test and ANOVA tests were applied to data. As a result, 4 dimensions for perceived service quality and 2 dimensions for customer loyalty were defined. The 4 dimensions of perceived service quality are: Reliability, physical appearance, willingness, and empathy. The two dimensions of customer loyalty are: behavioural loyalty and cognitive loyalty. According to multiple linear regression results, dimensions perceived service quality (reliability, physical appearance, willingness, and empathy) effects dimensions customer loyalty (behavioural loyalty and cognitive loyalty). Meaningful outcomes has emerged the participants also analyzed the differences regarding the characteristics.

\section{Giriş}

Son yıllarda hizmet sektörünün çok hızlı bir biçimde gelişmesi hizmet işletmeleri arasında yoğun rekabetin

\footnotetext{
* Sorumlu yazar/Corresponding author

e-posta: yusufocel@duzce.edu.tr
}

yaşanmasına neden olmaktadır. Bu hizmet sektörlerinden bir tanesi de bankacılık sektörüdür ve hizmet sektörü içerisindeki önemli kurumlardan bir tanesidir. Bankacılık sektörü Türkiye'de, aktif büyüklüğü ve yarattı̆ğ istihdam 
açısından önemli bir yer tutmakta olup ekonomi içinde büyük ağırlığa sahiptir (Arabacı, 2018). Ülke geneline bakıldığında bankalar, her geçen gün şube sayılarını arttırmakta ve yerli/yabancı banka sayısı hızla artmaktadır. 2018 Haziran ayı itibariyle ülkemizde faaliyet gösteren banka sayısı 52'dir. Mevduat bankaları sayısı 34, kalkınma ve yatırım bankaları sayısı 13 ve katılım bankaları sayıs1 5'dir. Mevduat bankaları ile kalkınma ve yatırım bankalarında toplam çalışan sayısı 193.815 kişidir (Türkiye Bankalar Birliği).

Bankaların sayısı göz önüne alındığında pazarlama faaliyetlerinin de gün geçtikçe arttığı ve tüketicileri ikna ederek müşteri bağl1lığ 1 oluşturabilmenin hayati önem kazandığı görülmektedir (Karamustafa ve Yıldırım, 2007:88). Banka sayılarının artmasıyla birlikte; internet bankacılığı, bireysel bankacılık, kurumsal bankacılık, danışmanlık hizmetleri vb. hizmet çeşitlerinde de artış gözlenmektedir. Özellikle de bireysel bankacılık hizmetlerinin önem kazandığı bir dönemde, bankaların, varlıklarını devam ettirip ayakta kalabilmek için ürün ve hizmetlerde kaliteye daha fazla önem vermeleri gerekmektedir. Bankalar bu yoğun rekabet ortamında algılanan kaliteye önem vererek müşteri odaklı hizmet vermek, müşterilerin memnuniyetini sağlamak ve bu memnuniyeti sadakate dönüştürmek durumundadırlar. Son dönemlerdeki hizmet sektöründeki sık1 rekabet nedeniyle müşteri memnuniyeti, müşteri tutma ve müşteri hizmetlerine odaklanmak herhangi bir bankanın varlığını devam ettirebilmesi için daha da önemli hale gelmiş ve bankacılık işlemlerinde de müşteri memnuniyeti anahtar faktör olarak kabul edilmiştir (Kaytancı vd.2013). Bunun içinde bankaların hizmet kalitelerini sürekli olarak ölçmek ve müşteri memnuniyetini değerlendirmek amacıyla Pazar yönlü olmaları gerekmektedir. Pazar yönlülük, tüketicilerin beklenti ve taleplerini dikkate almayı, pazar şartlarına duyarlı olmayı ve bu şartlara uygun yenilikler ve farklılıklar yaratmayı öngörmektedir (Karamustafa ve Yıldırım, 2007:58). İşletmeler, müşterilerin aldıkları hizmetler hakkında ne düşündüklerini doğru olarak belirleyemezlerse, varlıklarını uzun süre muhafaza edemeyebilirler. Fakat hizmetlerin bir takım özelliklerinden (soyutluk, stoklanamaz, değişken ve ayrılmaz oluşu) dolayı ölçümlerini yapmak kolay değildir.

Bireysel banka müşterileri üzerine yapılan bu çalışma da; müşterilerinin kullanmış oldukları bankalardan aldıkları ürün ve hizmetlerden algıladıkları kalitenin, sadakat üzerine etkisinin olup olmadığı incelenmektedir. Bankalardan hizmet alırken müşterileri ve banka personeli arasında kurulan iletişimlerin, sergilenen davranışların veya bulunulan ortamın özelliklerinden dolayı, müşteriler üzerinde hizmet kalitesine dair oluşan etkilerinin müşteri sadakati üzerinde bir etkisi olup olmadığı araştırılmıştır. Literatürde aynı hizmet sektörüne dair yapılan kamu ve özel karşılaştırmalı ya da sadece kamu bankası müşterileri üzerinden yapılan araştırmalar mevcuttur. Yapılan araştırmaların evrenleri ile bu araştırmanın evreni farklılık göstermektedir. $\mathrm{Bu}$ araştırma sadece Düzce de faaliyet gösteren kamu ve özel bankaların bireysel müşterileri üzerinden yapılan bir araştırmadır. Nitekim hizmetler heterojen yapıya sahip olduğu için işletmeler tarafindan standart hizmet sunulsa bile algilanan hizmet kalitesi bölgeden bölgeye, kişiden kişiye farklılık göstermektedir. Ayrıca çalışmada müşteri sadakati ve hizmet kalitesi kavramların demografik değişkenlere göre katılımcıların algılarına yönelik farklılık oluşup oluşmadığı incelenmektedir.

Çalışma dört bölümden oluşmaktadır. Çalışmanın ilk bölümünde kısaca araştırmaya giriş yapılmış ve konu özetlenmiştir. İkinci bölüm ve üçüncü bölümde algılanan hizmet kalitesi, müşteri sadakati kavramları açıklanmakta ve alan yazında yapılmış araştırmalar özetlenmektedir. Dördüncü bölümde ise yöntem kısmı yer almaktadır. Son bölümde ise çalışma kapsamında yapılan analizlerden elde edilen bulgular raporlanmakta ve yorumlanmaktadır.

\section{Algılanan Hizmet Kalitesi}

Kalite, müşterinin ihtiyaçlarını karşılayan ve dolayısıyla müşteri memnuniyetini sağlayan ürünler anlamına gelir ve ayrıca kalite, eksikliklerin, yani tekrarlanan hataların veya saha arızaları, müşteri memnuniyetsizliği, müşteri talepleri vb. yeniden düzenlenmesi anlamına da gelir (Juran,1998: 12). Hizmet ise, tüketicilerin mülkiyetle ilişkisi olmaksızın satın aldıkları faydalar olarak tanımlar (Mucuk, 1994). Hizmetler ise, insanlar veya makineler tarafindan sunulan tüketicilere fayda sağlayan ve fiziki varlığı olmayan ürünlerdir (Üzerem,1997:34). Hizmetlerin soyut, dayanıksız, değişken ve ayrılamaz özellikte oluşlarından dolayı kalitesinin ölçülmesi oldukça zor olmaktadır. Bu zorluklara karşı bir hizmet işletmesi, müşteriler tarafindan nasıl değerlendirildiğini bilmek ve müşteri beklentilerini daha iyi anlayabilmek amacıyla hizmet kalitesini ölçmek zorundadır (Yılmaz, vd., 2007:300). Algilanan hizmet kalitesi ise, Parasuraman ve arkadaşlarına (1988) göre müşterilerin bir hizmeti almadan önce kendilerinde oluşan beklenti ile onlara sunulan hizmetin karşılaştırılması sonucu elde edilen değerdir (Parasuraman vd., 1988). Parasuraman vd. tarafindan SERVQUAL, Cronin ve Taylor tarafindan SERPERF modeli geliştirilmiştir. Her ikisi de literatür de yaygın olarak hizmet kalitesi ölçümünde kullanılmaktadır. Parasuraman vd. tarafindan geliştirilen SERVQUAL modelinde hizmet kalitesi yerine, "algılanan hizmet kalitesi" deyimi kullanılmakta ve SERVQUAL hizmet kalitesi ölçeği beş boyut altında yer alan 22 sorudan oluşmaktadır. SERVPERF hizmet kalitesi ölçeğinde ise, Parasuraman vd. SERVQUAL için geliştirdikleri 22 ifade ve 5 boyut aynı şekilde vardır. Fakat SERVPERF ölçeği ile müşterilerin bu maddelere verdikleri önem, beklentileri ve algılamaları aynı anda ölçülebilmekte ve değerlendirilebilmektedir. Ayrıca algılanan hizmet kalitesi daha belirgin bir şekilde hesaplanabilmektedir (Aydın ve Y1ldırım,2012).

Hizmet kalitesi ile ilgili genel kabul görmüş ve hizmet kalitesinin boyutlarını ortaya koyan çalışmalar Parasuraman, Zeithaml ve Berry tarafından yapılmıştır. Hizmetleri tipine göre ayırt etmeksizin temel kriterler belirlemişlerdir. Bu kriterleri on ana kategoriye ayırmışlar ve bu kriterlere hizmet kalitesinin boyutları ismi verilmiştir. $\mathrm{Bu}$ boyutlar ise şunlardır; fiziksel varlıklar, güvenilirlik, güvenlik, iletişim, erişilebilirlik (ulaşılabilirlik) yanıt verilebilirlik, inanılırlık, karşılık verebilmek, yeterlilik, saygı, müşteriyi anlamaktır (Zeithaml vd.,1990, s.20-22). Parasuraman, Zeithaml ve Berry' nin bu alandaki çalışmaları devam ettikçe algılanan hizmet kalitesinin on boyutundan aslında sadece beş tanesinin yüksek düzeyde ilişkili olduğu ve bu boyutlarında kendi aralarında da etkileşim içerisinde oldukları sonucu 
çıkmıştır. Parasuraman vd. (1988) tarafından bu boyutlar şu şekilde tanımlanmıştır;

Somut/Fiziksel Özellikler: İşletmelerin hizmet sunumunda kullandığı araç gereçler, işletmenin çalışanlarının kılık kıyafeti, işletmenin fiziki çevresini oluşturan binanın dekorasyonuna bağlı görsel çekiciliği, aydınlatması, 1sısı vb.

Güvenilirlik: İşletmelerin verdikleri sözleri, söz verdikleri zamanda yerine getirmeleri, hizmetlerini ilk seferde ve doğru sunmaları ve hatasız kayıt tutmaları sıralanabilir.

Heveslilik(isteklilik): İşletme çalışan ve yöneticilerin müşterilere hizmet vermeye ve yardım etmeye hevesli olmaları, müşterilere hızlı hizmet verilmesi, çalışanların işlerini yerine getirmelerindeki istekliliği ve çalışanların müşterilerin isteklerine yanıt veremeyecek kadar meşgul olmaması şeklinde sıralanabilir.

Güvence: işletme çalışanların bilgili ve nazik olmalı ile birlikte müşteriye güven duygusu oluşturabilme becerileridir.

Empati: İşletme çalışanlarının kendilerini müşterilerinin yerine koymaları, işletmenin müşterilerine bireysel ilgi gösterilmesi, işletmenin çalışma saatlerinin müşteriler için uygun olması, işletme çalışanlarının müşteriyi ve ihtiyaçlarını anlamak için özen göstermeleri ile çalışanların müşterilerin ihtiyaçlarından anlaması olarak sıralanabilir.

Literatüre bakıldığında hizmet kalitesiyle ilgili bankacılık sektöründe birçok çalışmanın yapıldığı görülmektedir. Tüfekçi ve Tüfekçi (2006), bankacılık sektöründe farklı olma ve üstünlüğün ve müşteri sadakatinin yarattığ 1 değer isimli çalışmaları sonucunda SERVQUAL ölçüm faktörlerinden güvenirlilik ve heveslik faktörlerinden elde edilen tatmin düzeyinin arttıkça bankalara olan sadakatin de arttığına ulaşmışlardır. Çiftçi (2006), hizmet kalitesi ve bankacılık sektöründe hizmet kalitesinin ölçülmesi adlı çalışmasında, banka müşterilerinin en fazla önem verdikleri hizmet kalitesi boyutun güvenilirlik olduğunu; en az önem verdikleri boyutun ise, fiziksel özellikler olduğu sonucunu bulmuştur. Yılmaz vd. (2007:244), banka müşterilerinin mükemmel bankalardan bekledikleri hizmet ile müşterisi oldukları bankalardan aldıkları hizmetlerde bir takım açıklıkların olduğu ve beklenen hizmeti alamadıkları sonucuna ulaşmışlardır. SERVQUAL ölçeğinin kullanıldığı araştırmada müşterilerin en fazla heveslilik boyutunda memnun olmadıkları ortaya çıkmıştır. Öncü vd. (2010), Bankacılık sektöründe hizmet kalitesinin ölçmek amacıyla yaptıkları çalışmalarında, banka müşterilerinin banka tercihlerinde etkili olan en önemli faktörün bankaların güvenilir olması ve müşteri ilişkilerine önem vermesi olarak ortaya çıkmıştır. Bülbül vd. (2012), SERQUAL ölçeğini kullanarak, "Türk bankacıllk sektöründe hizmet kalitesinin müşteri tatmini ve tekrar satın alma niyeti üzerine etkisi” adlı çalışmalarında, özel bir bankanın müşterilerine anket uygulamışlardır. Analiz sonuçlarına göre; müşterilerin hizmet kalitesi algılamaları beklentilerin altında kalmıştır. Boyutlar açısından bakıldığında ise; müşterilerin en fazla memnun olduğu boyut: somutluluk, müşterilerin en az memnun olduğu boyut ise: yanıt verilebilirlik olduğu ortaya çıkmıştır. Ustasüleyman ve Eyüboğlu'nun (2010) yaptığı çalışmada internet bankacılığında tüketicilerin kullanım niyeti ile güven, web güvenliği, kolaylık ve kullanışlılık arasında anlamlı ilişkiler çıkmıştır. Dolayısıyla bankacılık sektöründe güven önem arz etmektedir. Işık vd.(2013),
SERVPERF ölçeğini kullanarak, banka müşterilerinin bağlılıklarını etkileyen hizmet kalitesi algılarını araştırmışlardır. Araştırma sonuçlarına göre; empati ve güvenirlilik kalite boyutlarının daha sonra hizmet alma, hizmet kalitesi ve memnuniyet üzerinde olumlu etkisi olurken, hizmet kalitesi boyutlarından somutluluk, cevap verebilirlik ve güvencenin daha sonra hizmet alma düşüncesi, genel kalite ve memnuniyet üzerinde olumlu bir etkisinin olmadığını bulmuşlardır. Yücel'in (2013), bankacılık sektöründe SERVQUAL analizini kullanarak, müşterilerin bankalarına ilişkin algılanan hizmet kalitesini ölçmek amacıyla yaptığı araştırma neticesinde; müşterilerin kullandıkları bankanın müşteri beklentilerini karşılayamadığını yani bankada sunulan hizmete yönelik müşteri kalite algısının düşük olduğu tespit edilmiştir. Onan'nın (2017), SERVPERF ölçeğini kullanarak "Bankacılık sektöründe hizmet kalitesinin marka bağlılığı üzerine etkisi" adlı çalışmasında, hizmet kalitesinin, güvenirlilik ve güvence boyutlarının müşterilerin banka marka bağlılığı üzerinde olumlu etkileri olduğunu fakat diğer boyutlar olan fiziksel görünüm, yanıt verilebilirlik ve empatinin banka marka bağımlılığına herhangi bir etkisinin olmadığı sonucuna varılmıştır.

\section{Müşteri Sadakati}

Müşteri sadakatinin literatür de birçok tanımı bulunmaktadır. Birçok araştırmacı tarafından farklı şekillerde tanımlanmaya çalışılmıştır. Oyman, (2002) tarafından, müşteri sadakati, bir markaya ya da işletmeye duyulan bağlılık olarak tanımlanmıştır. Daha kapsamlı tanımlar da ise, "müşterinin kendisi için başka alternatiflerinde mevcut olduğu bir ortamda, belirli bir işletmeye, satıcıya ya da ürün veya hizmete (markaya) yönelik duyduğu, hissettiği, içten (duygusal) bağlılık ve tesadüfi olmayan alışveriş eğilimi (tutumu), arzusu ve eylemidir" şeklinde tanımlanmıştır (Bayruk ve Küçük, 2007:287). Diğer bir tanımda ise, müşteri sadakati: "rakiplerin daha düşük fiyatlar ve kuponlar teklif etseler dahi, bir müşterinin herhangi bir alternatifi yerine tek bir markayı tekrar tekrar arama ve satın alma yeteneği olarak tanımlanabilir', şeklindedir (Yıldız ve Çilingir, 2010: 413). Özer ve Günaydın, (2010) ise müşteri sadakatini, müşterilerin işletmeye karşı olumlu manevi duyguları, üretilen mal ve/ya da hizmeti tekrar satın alma eğilimi ve işletmeyi başkalarına tavsiye etme durumu şeklinde tanımlamışlardır. Sadakatin oluşmasında alışkanlık, rahatlık, tembellik, uygunlık ve zaman tasarrufu etkili olmaktadır (Dick ve Basu, 1994:75)

Literatürde müşteri sadakati türleri üç başlık içinde incelenmektedir. Bunlar; davranışsal sadakat, tutumsal sadakat ve karma (bilişsel) sadakattir. Davranışsal sadakat; müşterilerin tekrar satın alma davranışlarına dayanmaktadır. Bu sadakat türünde önemli olan satın alma niyeti geliştirmek ve tekrar tekrar satın almaktır (Altıntaş, 2000:32). Diğer bir deyişle tüketicilerin bir markayı tüm yaşamları boyunca satın alma sıklıkları ve satın alma miktarları davranışsal sadakatin kapsamını oluşturur (Tosun, 2014:152). Tutumsal sadakat; bir işletmeye yönelik müşterinin sadece tekrarlı satın alma davranışını içermeyen aynı zamanda da müşterinin işletmeye karşı yüksek talepli, uzun dönemli bağlılığını temsil etmektedir (Yıldırım, 2005). Tüketicilerin markayı çok sevmeleri, kullanamama durumunda onu özleyeceklerini hissetmeleri, markayı ürünün işlevlerini aşan bir unsur 
olarak görmeleri tutumsal bağlılı̆̆ın ön koşuludur (Tosun, 2014:155). Karma (bilişsel) sadakat; Bu sadakat türü hem tutumsal hem de davranışsal sadakat türünün bir karışımı olup, sadakat kavramını; satın alma sıklığına, miktarına, zamanına, ürün tercihine ve marka değiştirme eğilimine göre açıklamaktadır (Değermen, 2006: 79).

Bir müşteri işletmeye olan bağlılı̆̆ı bir anda oluşmamaktadır. Zamanla oluşan sadakat farklı seviyelerde gerçekleşebilmektedir. Bu duruma müşteri sadakat düzeyleri denilmektedir. Müşteri sadakat düzeyleri dört şekilde gerçekleşmektedir. Bunlar; mutlak sadakat (gerçek sadakat), gelişmemiş sadakat (gizli sadakat), yüzeysel sadakat ve sadakatsizliktir (Dick ve Basu, 1994:101; Tosun, 2014:252253). Bu düzeyler aşağıda açıklanmaktadır.

Mutlak sadakat; bu sadakat türünde tüketicilerin yöneldikleri markalarla ilgili olumlu duygu ve düşüncelerinin yanında tekrar satın alma durumları da söz konusudur.

Gelişmemiş sadakat; bu sadakat türünde ise tüketicilerin yöneldikleri markalarla ilgili olumlu duygu ve düşünceleri bulunurken, tekrar satın alma durumları bulunmayabilir. Örneğin tüketici bir banka hakkında olumlu duygu ve düşüncelere sahip olabilir. Fakat yeterli mevduatı veya menkulü olmadığı için yatırım yapamayabilir.

Yüzeysel sadakat (gizli sadakat); bu sadakat türünde ise tüketiciler yöneldikleri markaları tekrar tekrar satın almalarına karşın, marka ile ilgili herhangi bir duygusal bağ kuramayabilir. Bir müşterinin aynı bankadan tekrar tekrar hizmet almasına karşın o banka ile ilgili olumlu duygu ve düşünceleri olmaması, başkalarına tavsiye etmemesi örnek gösterilebilir.

Sadakatsizlik; tüketicilerin hem olumlu duygu ve düşüncelerinin düşük, hem de tekrar satın alma davranışlarının düşük olduğu bir düzeydir. McGoldrick ve Andre (1997:75) göre; sadakatsizliğin müşteriden kaynaklanan özellikleri: Akıllılık, adama, para tasarrufu, katmerli eğlence, merak, vakit öldürmedir.

Literatür' de müşteri sadakati ile ilgili yapılmış farklı çalışmalar görmek mümkündür. Bunlardan bazıları şunlardır:

Sütütemiz ve Çiftyıldız,(2006) Türk bankacılık sektöründe, müşteri sadakati ile onun belirleyicileri arasındaki ilişkileri incelemek ve literatürdeki mevcut kurumsal modellerin hangisinin daha iyi uyum vereceğini araştırmak amacıyla Türkiye'nin dört ilinde bir anket uygulaması yapmışlardır. Çalışma sonuçlarına göre; bankacılık sektöründe müşteri sadakatinin temel belirleyicisinin tatmin olduğu ortaya çıkarılmıştır. Demirören (2009), Türkiye' de faaliyet gösteren ve temsilen seçilen bölgelerdeki illerdeki banka müşterileri üzerine uygulan anket çalışmasında, müşteri ilişkileri yönetimi uygulamaları ile müşteri tatmini ve müşteri sadakati ilişkisini araştırmıştır. Yapılan çalışma neticesinde banka müşterilerinin değerlendirmeleri ile müşteri tatmini ve müşteri sadakati arasındaki anlamlı ilişkiler saptamıştır. Bu ilişkinin düzeyi müşteri tatminin müşteri sadakatine göre daha fazla olduğudur. Koçer, (2017) bankacılık sektöründe uygulanan müşteri ilişkileri yönetimi uygulamalarının müşteri sadakati üzerinde etkili olduğunu saptamıştır. Çıkan sonuçlara göre müşteri sadakati üzerinde hizmet sunumu, kaliteli ve faydalı hizmet anlayışı, beklentilere karşılık verme ve hizmet farkındalığ sağlamanın müşteri sadakati üzerinde etkili olduğu ortaya çıkmıştır.

\section{Araştırmanın Evreni, Örneklemi, Yöntemi, Modeli ve Hipotezleri}

Bu çalışma ile bireysel banka müşterilerinin hizmet kalitesi algılarının müşteri sadakati üzerine etkisini değerlendirmek amaçlanmıştır. Bu araştırmanın evrenini Düzce ilinde ikamet eden 18 yaş üstü, bireysel banka müşterileri oluşturmaktadır. Araştırmada, örnekleme yöntemi olarak tesadüfi olmayan örnekleme yöntemlerinden kolayda örnekleme yöntemi uygulanmıştır.

Düzce'de faaliyet gösteren bankalar, Akbank, Albaraka, Deniz Bank, Fıba Bank, Finans, Garanti Bankası, Halkbank, ING Bank, İş Bankası, Kuveyt Türk, Şeker Bankası, TEB, Vakıfbank, Yapı Kredi Bankası ve Ziraat Bankası'dır. Anketler, bu bankaların bireysel müşterilerine uygulanmıştır. 01.05.2018 ile 01.09.2018 tarihleri arasında yüz yüze gerçekleştirilen anket görüşmesinden elde edilen veriler kullanılarak, bireysel banka müşterilerinin hizmet kalitesi algılarının müşteri sadakatleri üzerine etkisi incelenmiştir. Araştırma desenine uygun oluşturulan model şekil-1'de görülmektedir. 2017 yılı adrese dayalı nüfus kayıt sistemine göre Düzce nüfusu 377.610 kişidir (http://www.tuik.gov.tr/). Bu doğrultuda 377.610 kişinin yaşadığı Düzce şehrini $\% 5$ hata payı ve $\% 95$ güven aralığın da 384 kişilik bir örneklem temsil edebilmektedir. Bu kapsamda araştırmada 384 kişiye anket uygulanmış ve bu anketlerin tamamı değerlendirmeye alınmıştır. Anket formu üç bölümden oluşmaktadır. Birinci bölümde; kişisel bilgilere yer verilmiştir. $\mathrm{Bu}$ bölümde ankete katılanların cinsiyeti, yaşı, medeni hali, eğitim durumları, meslekleri ve gelir durumları ile ilgili demografik sorular yer almaktadır. İkinci bölümde ise, SERPERF ölçeğine göre hazırlanan sorular yer almaktadır. Hizmet kalitesini ölçmek amacıyla birçok yöntem kullanılmaktadır. Bu yöntemlerden bir tanesi de SERVPERF yöntemidir. SERVPERF ölçeği literatürde kabul görmüş hizmet kalitesi ölçeklerinden biridir. Cronin ve Taylor (1992), tarafından literatüre kazandırılmıştır. Literatürde yaygın olarak kullanılan SERVQUAL ölçeği ile benzer olan SERVPERF ölçeği, sadece hizmet performansına odaklanmakta ve müşteri algılarını hedef almaktadır. Cronin ve Taylor (1992), SERVPERF ölçeğini, özel banka, kuru temizleme, fast-food haşere kontrol olmak üzere dört hizmet sektöründe denemişlerdir. Daha sonra yurt içinde ve yurt dışında birçok araştırmacı tarafından, eğitim, sağlık ve finans gibi birçok alanda kullanılmıştır. Bu çalışmada da SERVPERF yöntemi kullanılarak bireysel banka müşterilerinin hizmet kalitesi algılarının müşteri sadakati üzerine etkisi olup olmadığı incelenmiştir. Üçüncü bölümde ise Müşteri sadakati ile ilgili sorular yer almaktadır. Müşteri sadakatine ait ölçek ise, daha önce bu alanda çalışan Gümüşbuğa'nın (2015) çalışmasından uyarlanmıştır. Ölçekte değişiklik yapılmadan alınmış ancak ölçek ifadeleri araştırmaya uygun olarak adapte edilmiştir. Algılanan hizmet kalitesi ve müşteri sadakatine ilişkin değişkenler 5'li likert tipi ölçekle (1-kesinlikle katılmıyorum, 2katılmiyorum, 3- fikrim yok, 4- katıliyorum, 5- kesinlikle katılıyorum) şeklinde oluşturulmuştur. 


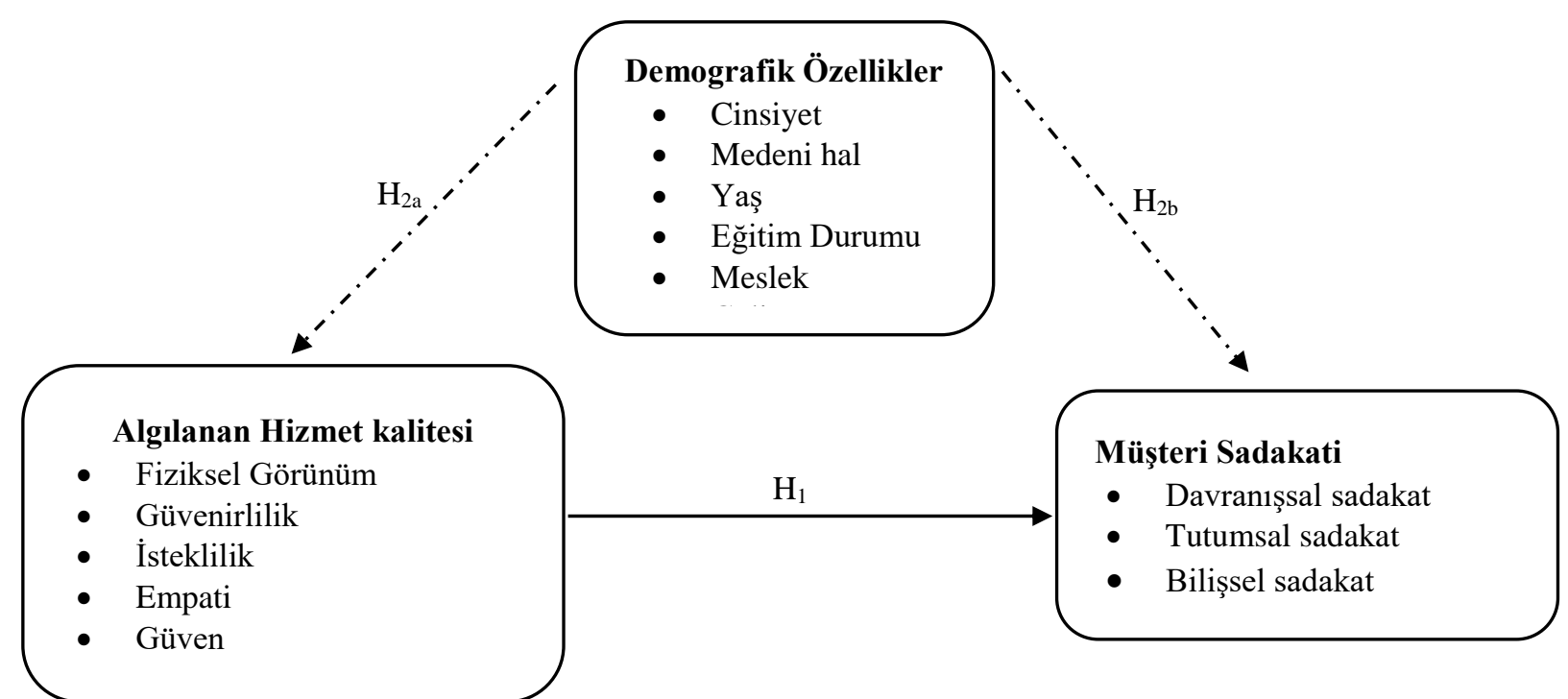

Şekil 1: Araştırmanın Modeli

Araştırma modeline uygun oluşturulan temel ve alt hipotezler aşağıda görülmektedir. Literatür kısmında yapılan detaylı araştırmalar sonucunda bireysel banka müşterilerinin hizmet kalitesi algılarının müşteri sadakatine etki ettiği düşünülmektedir. Bu kapsamda oluşturulan temel hipotez aşağıdaki şekildedir.

Temel hipotez: "H: "bireysel banka müşterilerinin hizmet kalitesi algıları müşsteri sadakatini etkilemektedir.”

\section{Alt hipotezler:}

Müşterilerin hizmet almak için gittikleri bankalar da; işletmenin fiziksel ortamının, ekipmanının ve personelinin görünüşünün insanlar üzerinde olumlu bir etki yaratacağı ve sadakati artıracağı düşünülerek $\boldsymbol{H}_{\mathbf{I a}, \boldsymbol{b}, \boldsymbol{c}}$ alt hipotezi oluşturulmuştur. Ha,b,c: "bireysel banka müşterilerinin algılanan hizmet kalitesi boyutlarından "fiziksel görünüm”, müşsteri sadakati boyutlarından a)davranışsal sadakati, b)tutumsal sadakati c)bilişsel sadakati etkilemektedir',

Günümüzde hizmet alırken müşterilerin en fazla önem verdikleri özelliklerden biri de güvenilirliktir. Bankalardan alınan hizmetlerin zamanında doğru bir şekilde ve güvenilir olarak alınmasının, müşteriler üzerinde olumlu bir etki yaratıp sadakati artacağı düşünülerek $\boldsymbol{H}_{1 d, \boldsymbol{e}, f}$ alt hipotezi oluşturulmuştur. Hid,e,f: "bireysel banka müşterilerinin algılanan hizmet kalitesi boyutlarından "güvenirlilik", müşteri sadakati boyutlarından d)davranışsal sadakati, e)tutumsal sadakati f)bilişsel sadakati etkilemektedir'.

Bankalar yoğun müşteri trafiğinin yaşandığı işletmeler olduğu için, müşteriler banka çalışanlarından hızlı bir şekilde hizmet almak ve banka çalışanlarının kendilerine yardım etmeye hevesli olmasını isterler. Buradan hareketle; banka personelin/ yöneticilerin müşterilere yardım etme isteği ve hızlı bir şekilde hizmet sunmasının müşteri sadakatini arttıracağ1 düşünülerek $\boldsymbol{H}_{l g, h, i}$ alt hipotezi oluşturulmuştur. $H_{1 g, h, i:}$ "bireysel banka müşterilerinin algllanan hizmet kalitesi boyutlarından "heveslilik", müşteri sadakati boyutlarından g)davranıssal sadakati, h)tutumsal sadakati i)bilişsel sadakati etkilemektedir'”.
Banka çalışanlarının kendilerini, müşterilerinin yerine koyabilmeleri, müşterilerin düşüncelerine saygı göstermeleri ve müşterilerin her birine duyarlı davranarak bireysel özen göstermelerinin müşteri sadakatini olumlu yönde etkileyeceği düşünülerek $\boldsymbol{H}_{l j, k, l}$ alt hipotezi oluşturulmuştur. $H_{l j, k, l}:$ "bireysel banka müşterilerinin algllanan hizmet kalitesi boyutlarından "empati", müşteri sadakati boyutlarından j)davranışsal sadakati, k)tutumsal sadakati l)bilişsel sadakati etkilemektedir'”

Müşterilerin bir bankadan hizmet alırken karşılarındaki personelin/yöneticinin tavırları hizmetin oluş aşamasında ve hizmeti satın aldıktan sonra da; bir sorunla karşılaşıp müracaat ettiklerinde gördükleri muamele, o banka ile tekrar iş yapıp yapmama davranışlarında yüksek bir etkiye sahip olacaktır. Bu itibarla; banka çalışan ve yöneticilerinin bilgi düzeyleri, nezaketleri ve müşterilere güven vermelerinin, müşteri sadakatini artıracağı düşünülerek $\boldsymbol{H}_{\boldsymbol{l m}, \boldsymbol{n}, \boldsymbol{o}}$ alt hipotezi oluşturulmuştur. H Hm,no: 'bireysel banka müşterilerinin algılanan hizmet kalitesi boyutlarından "güven", müşseri sadakati boyutlarından m)davranısssal sadakati, $n$ )tutumsal sadakati o)bilişsel sadakati pozitif yönde ve anlamlı olarak etkilemektedir',

Katılımcıların demografik özellikleri ile bağımlı ve bağımsız değişkenler arasındaki farklılıklara yönelik hipotezler aşağıdaki gibidir:

Temel hipotez: $H_{2 a, b}$ : Katılımcıların demografik özellikleri ile a) algılanan hizmet kalitesine yönelik ve b) müşteri sadakatine yönelik algıları arasında anlamlı farklılıklar vardir.

\section{Bulgular}

$\mathrm{Bu}$ bölümde çalışmada elde edilen verilere uygulanan frekans, faktör, korelasyon, regresyon ve farklılık analiz sonuçları yer almaktadır.

\subsection{Demografik Bulgular}

Katılımcıların demografik özelliklerine yönelik frekans analiz sonuçları tablo-1'de gösterilmektedir. Katılımcılara ait demografik veriler incelendiğinde kadın katılımcılar \% 51'ini,erkek katılımcılar ise \% 48 ini oluşturmaktadır. 
Katılımcıların yaşlara göre dağılımı incelendiğinde \%31'nin 25-31, \%21'nin 32-38, \%20'sinin 18-24,\%17sinin 39-45 ve \%10'nun 46 yaş ve üzeri oldukları görülmektedir. Katılımcıların \%21'i özel sektör çalışanı, \%18'si öğrenci,\%15'i memur,\%13'ü ev hanım1,\%6's1 serbest meslek çalışanı ve emekli ve de \%3'ünün işçi oldukları görülmektedir. Katılımcıların, \%35'i lisans, ,\%19'u lise, $\% 15$ 'i yüksekokul, \% 13'ü lisansüstü \% 12'si ilköğretim ve $\% 4$ 'ü doktora mezunu oldukları, gelir düzeylerinin ise \% 27 'sinin $2501-3500$, \% 21'sinin 1601-2500 ve \%20'sinin 4500 ve üzeri, $\% 19$ 'unun 3501-4500 ve\%11'nin 1600 ve alt gelir düzeyine sahip oldukları görülmektedir.

Tablo-2'de ise katılımcıların hangi bankayı daha çok tercih ettikleri ile ilgili frekans analiz sonuçları yer almaktadır. Katılımcıların, "kullandığınız banka hangisidir" ifadesine verilen cevapları incelendiğinde, katılımcıların \%14,6'sı İş Bankası, \%14,1'i Ziraat Bankası, 10,9'u Finans Bank ve 10,7'si Halk Bankası şeklinde cevaplandırdıkları görülmektedir. En çok tercih edilen bankanın İş bankası olduğu anlaşılmaktadır.

Tablo1. Araştırmaya Katılanların Demografik Özellikleri

\begin{tabular}{|c|c|c|c|}
\hline & & $\mathrm{n}$ & $\%$ \\
\hline \multirow{2}{*}{ Cinsiyet } & Kadın & 197 & 51,3 \\
\hline & Erkek & 187 & 48,7 \\
\hline \multirow{5}{*}{ Yaş } & $18-24$ & 77 & 20,1 \\
\hline & $25-31$ & 120 & 31,3 \\
\hline & $32-38$ & 82 & 21,4 \\
\hline & $39-45$ & 66 & 17,2 \\
\hline & 46 ve üstü & 39 & 10,2 \\
\hline \multirow{6}{*}{ Eğitim durumu } & İlköğretim & 46 & 12,0 \\
\hline & Lise & 76 & 19,8 \\
\hline & Yüksekokul & 59 & 15,4 \\
\hline & Lisans & 135 & 35,2 \\
\hline & Lisansüstü & 51 & 13,3 \\
\hline & Doktora & 17 & 4,4 \\
\hline \multirow{8}{*}{ Meslek } & Memur & 61 & 15,9 \\
\hline & Özel sektör ç. & 84 & 21,9 \\
\hline & Serbest m. & 26 & 6,8 \\
\hline & Emekli & 15 & 3,9 \\
\hline & Ev hanımı & 53 & 13,8 \\
\hline & Öğrenci & 70 & 18,2 \\
\hline & İşçi & 23 & 6,0 \\
\hline & Çalışmiyor & 52 & 13,5 \\
\hline \multirow{2}{*}{ Medeni durum } & Bekâr & 189 & 49,2 \\
\hline & Evli & 195 & 50,8 \\
\hline \multirow{5}{*}{ Gelir düzeyi } & 1600 ve alt1 & 45 & 11,7 \\
\hline & $1601-2500$ & 81 & 21,1 \\
\hline & $2501-3500$ & 105 & 27,3 \\
\hline & $3501-4500$ & 73 & 19,0 \\
\hline & 4501 ve üzeri & 80 & 20,8 \\
\hline
\end{tabular}

Tablo 2. Katılımcıların kullandıkları bankalar

\begin{tabular}{lll}
\hline \multicolumn{1}{c}{$\begin{array}{c}\text { Kullandı̆̆ınız } \\
\text { banka }\end{array}$} & Frekans & $\%$ \\
\hline İş Bankası & 56 & $\% 14,6$ \\
\hline Ziraat & 54 & $\% 14,1$ \\
\hline QNB & 42 & $\% 10,9$ \\
\hline Halk Bankası & 41 & $\% 10,7$ \\
\hline Garanti & 36 & $\% 9,4$ \\
\hline Akbank & 31 & $\% 8,1$ \\
\hline Kuveyt Türk & 29 & $\% 7,6$ \\
\hline Denizbank & 23 & $\% 6,0$ \\
\hline Vakıf Bank & 21 & $\% 5,5$ \\
\hline Teb & 21 & $\% 5,5$ \\
\hline Yapı Kredi & 10 & $\% 2,6$ \\
\hline Albaraka & 8 & $\% 2,1$ \\
\hline ING & 6 & $\% 1,6$ \\
\hline F1ba bank & 3 & $\% 0,8$ \\
\hline Şeker bank & 3 & $\% 0,8$ \\
\hline Toplam & 384 & $\% 100,0$ \\
\hline
\end{tabular}

\subsection{Faktör Analizi}

Araştırma da kullanılan verilerin normal dağılım gösterip göstermediğini belirlemek amaciyla verilere KolmogorovSmirnov testi uygulanmıştır. Uygulan test sonucuna göre algılanan hizmet kalitesi ve müşteri sadakatinde yer alan ifadelerin anlamlılık değerlerinin, $0.05^{\prime}$ 'den büyük olduğu ve normal dağılım gösterdiği gözlenmiştir. İlk olarak algılanan hizmet kalitesi ile ilgili faktör analizi yapılmıştır. Yapılan faktör analizi tablo-3'de görülmektedir. Araştırma kapsamında Temel Bileşenler Analizi ve Varimax rotasyon tekniği kullanılarak Keşfedici faktör analizleri uygulanmıştır. Barlett Küresellik testinin anlamlı olması ve en alt sınır değer olarak 0,70 (Büyüköztürk, 2010) kabul edilen Kaiser-Meyer-Olkin değerinin 0,951 olması örneklem büyüklüğünün faktör analizi için yeterli olduğunu göstermektedir. Cronbach's Alpha değerinin 0,967 olduğu görülmektedir. Algılanan hizmet kalitesinin faktör analizi sonucuna göre; birinci faktör 7 ifadeden, ikinci, üçüncü ve dördüncü faktörler 5 'er ifadeden oluşmaktadır.

$\mathrm{Bu}$ faktörler incelendiğinde ortaya çıkan boyutlar aşağıdaki gibidir; Tablo 3'e bakıldığında birinci faktörün yükleri 0,545 ile 0,805 değerleri arasında değişmektedir. Ankette yer alan ifadeler bireysel banka müşterilerin hizmet aldıkları bankaya güven duymaları, tutulan kayıtların doğruluğu, çalışan davranışları ve uygulanan hizmetlerin doğruluğu ifadelerinden oluştuğu için bu faktöre "güvenilirlik" ismi verilmiştir. İkinci faktörün yükleri 0,709 ile 0,881 değerleri arasında değişmektedir. Ankette yer alan ifadeler müşterilerin özel ihtiyaçlarının anlayışla karşılanması, yapılan işlemlerin saatlerinin müşterilere uygun olması ve müşterilerin her biriyle özel ilgilenilmesi ile ilgili ifadelerden oluştuğu için "empati" ismi verilmiştir. Üçüncü faktörün yükleri 0,713 ile 0,863 değerleri arasındadır. Ankette yer alan sorular bireysel banka müşterilerinin hizmet aldıkları bankaların iç ve dış görünümü, işletmeyi oluşturan araç ve donanımı, hizmet sunumunda kullanılan materyallerin 
görünümü ile ilgili ifadeler birlikte düşünüldüğünde bu

faktöre "fiziksel görünüm" ismi verilmiştir.

Tablo 3. Algılanan Hizmet Kalitesi ile İlgili Faktör Analizi Sonuçları

\begin{tabular}{|c|c|c|c|c|c|c|}
\hline $\begin{array}{l}\text { Alt } \\
\text { boy. }\end{array}$ & İfadeler & Ort. & $\begin{array}{l}\text { Faktör } \\
\text { yük. }\end{array}$ & $\begin{array}{l}\text { Varyan } \\
\mathrm{s}\end{array}$ & $\begin{array}{c}\text { Öz } \\
\text { değer }\end{array}$ & $\begin{array}{l}\text { Cronba } \\
\text { ch's } \\
\text { Alpa } \\
\text { değeri }\end{array}$ \\
\hline \multirow{7}{*}{ 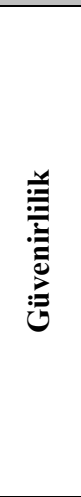 } & $\begin{array}{l}\text { Tercih ettiğim bankanın çalışanları bana karşı her zaman saygılı ve } \\
\text { naziktirler. }\end{array}$ & 3,60 &, 805 & \multirow{7}{*}{59,210} & \multirow{7}{*}{13,026} & \multirow{7}{*}{0,951} \\
\hline & $\begin{array}{l}\text { Tercih ettiğim bankanın çalışanlarının davranışları bende güven duygusu } \\
\text { uyandırır. }\end{array}$ & 3,47 &, 788 & & & \\
\hline & Tercih ettiğim bankadan aldığım hizmete ilişkin güven duyarım & 3,57 & ,777 & & & \\
\hline & $\begin{array}{l}\text { Tercih ettiğim bankanın çalışanları yardım etmeye her zaman istekli ve } \\
\text { gönüllüdürler. }\end{array}$ & 3,58 & ,734 & & & \\
\hline & $\begin{array}{l}\text { Tercih ettiğim banka hizmetlerle ilgili kayıt ve faturalama işlemlerinde } \\
\text { dürüst ve güvenilirdir. }\end{array}$ & 3,60 & ,734 & & & \\
\hline & $\begin{array}{l}\text { Tercih ettiğim banka, benim bir problemim olduğunda çalışanları probleme } \\
\text { yaklaşımlarında güven verici, ilgili ve cana yakındırlar. }\end{array}$ & 3,55 & ,726 & & & \\
\hline & $\begin{array}{l}\text { Kullandığım bankanın çalışanları hiçbir zaman benim isteklerime cevap } \\
\text { veremeyecek kadar meşgul değildirler. }\end{array}$ & 3,58 &, 545 & & & \\
\hline \multirow{5}{*}{ 㺼 } & Kullandığım banka bana özel ilgi gösterir. & 3,32 & ,881 & \multirow{5}{*}{9,583} & \multirow{5}{*}{2,108} & \multirow{5}{*}{0,954} \\
\hline & Kullandığım banka benim çıkarlarımı her şeyin üstünde tutar. & 3,08 & ,860 & & & \\
\hline & Kullandığım banka benim özel isteklerimi anlar. & 3,04 & ,847 & & & \\
\hline & Kullandığım bankanın çalışma saatleri bana uygundur. & 3,11 & ,840 & & & \\
\hline & Kullandığım bankanın çalışanları benimle kişisel olarak ilgilenir. & 2,97 & ,709 & & & \\
\hline \multirow{5}{*}{ 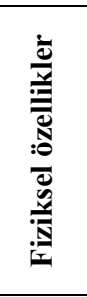 } & Tercih ettiğim bankanın fiziksel olanakları görsel açıdan çekicidir & 3,32 & ,863 & \multirow{5}{*}{7,507} & \multirow{5}{*}{1,651} & \multirow{5}{*}{0,927} \\
\hline & Tercih ettiğim banka teknolojiye uygun ve çağdaş donanıma sahiptir & 3,42 & ,861 & & & \\
\hline & $\begin{array}{l}\text { Tercih ettiğim bankanın hizmet verirken kullandığı malzemeler gözüme } \\
\text { hoş görünür. }\end{array}$ & 3,52 & ,806 & & & \\
\hline & Tercih ettiğim bankanın çalışanları temiz ve düzgün görünüşlüdür & 3,45 & ,796 & & & \\
\hline & $\begin{array}{l}\text { Tercih ettiğim banka sundukları hizmetin yanı sıra sundukları ek hizmetleri } \\
\text { de çekicidir. }\end{array}$ & 3,53 &, 713 & & & \\
\hline \multirow{5}{*}{ 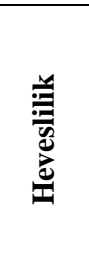 } & Tercih ettiğim banka hizmetlerini ilk anda yerine getirir. & 3,58 & 781 & \multirow{5}{*}{4,573} & \multirow{5}{*}{1,006} & \multirow{5}{*}{0,946} \\
\hline & $\begin{array}{l}\text { Tercih etiğim bankanın çalışanları, benim alacağım hizmeti mümkün olan } \\
\text { en kısa sürede verirler. }\end{array}$ & 3,54 & ,761 & & & \\
\hline & Tercih ettiğim bankanın çalışanları benim isteklerime hemen cevap verirler & 3,74 & ,755 & & & \\
\hline & Tercih ettiğim banka vaat ettikleri hizmeti zamanında yerine getirir. & 3,72 & ,732 & & & \\
\hline & $\begin{array}{l}\text { Tercih ettiğim bankanın çalışanları bana hizmetin tam olarak ne zaman } \\
\text { gerçekleşeceğini söylerler. }\end{array}$ & 3,83 & ,703 & & & \\
\hline 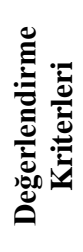 & \multicolumn{6}{|c|}{$\begin{array}{c}\text { Kaiser-Meyer-Olkin Measure of Sampling Adequacy } \\
\text { Approx. Chi-Square: } 9281,933 \\
\text { Barlett's Test of Sphericity: 0,000 } \\
\text { Extraction Method: Principal Components } \\
\text { Rotation Method: Varimax } \\
\text { Açıklanan Varyans Toplamı: } 0,80 \\
\text { Cronbach's Alpha: } 0,967 \\
\end{array}$} \\
\hline
\end{tabular}

Dördüncü faktörün yükleri ise 0,781 ile 0,703 arasında değişmektedir. Ankette yer alan sorular bankada çalışan personelin hizmeti sunmadaki istekli, arzulu davranışları ile ilgili algısını oluşturan ifadelerden oluştuğu için bu faktöre de "isteklilik (heveslilik)" ismi verilmiştir.

Müşteri sadakati ile ilgili yapılan faktör analizi tablo-4' de görülmektedir. Cronbach's Alpha değerinin 0,956 olduğu görülmektedir. Birinci faktördeki ifadeler birlikte düşünüldüğünde faktöre: "bilişsel sadakat", ikinci faktördeki ifadeler birlikte düşünüldüğünde faktöre: "davranışsal sadakat" ismi verilmiştir. Bilişsel sadakat ile ilgili 9 ifade, Davranışsal sadakat ile ilgili 6 ifade ilgili faktöre yüklenmiştir. Tablo da en düşük yükleme oranı 0,644 en yüksek yükleme oranı 0,874 olarak saptanmıştır. 
Tablo 4. Müşteri Sadakati ile İlgili Faktör Analizi

\begin{tabular}{|c|c|c|c|c|c|c|}
\hline $\begin{array}{l}\text { Alt } \\
\text { boy. }\end{array}$ & İfadeler & Ort. & $\begin{array}{l}\text { Faktör } \\
\text { yük. }\end{array}$ & Varyans & $\begin{array}{c}\text { Öz } \\
\text { değer }\end{array}$ & $\begin{array}{l}\text { Cronbach } \\
\text { 's Alpa } \\
\text { değeri }\end{array}$ \\
\hline \multirow{9}{*}{ 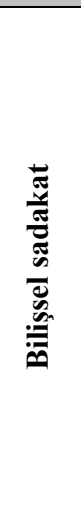 } & $\begin{array}{l}\text { Kullandığım bankanın ürün ve hizmet fiyatlarında artış olsa dahi } \\
\text { tercihimi değiştirmem }\end{array}$ & 2,52 & 0,858 & \multirow{9}{*}{63,787} & \multirow{9}{*}{9,568} & \multirow{9}{*}{0,940} \\
\hline & $\begin{array}{l}\text { Kullandığım bankanın rakipleri daha iyi fiyat sunsa bile tercihimi } \\
\text { değiştirmem }\end{array}$ & 2,58 & 0,851 & & & \\
\hline & $\begin{array}{l}\text { Kullandığım banka da işlem yapmak için fazladan mesafe kat etmekten } \\
\text { çekinmem. }\end{array}$ & 2,78 & 0,798 & & & \\
\hline & $\begin{array}{l}\text { Kullandığım banka ile ilgili olumlu yorumlarda bulunur, olumsuz } \\
\text { yorumlardan kaçınırım. }\end{array}$ & 2,83 & 0,728 & & & \\
\hline & $\begin{array}{l}\text { Kullandığım bankayla ile ilgili bir konu geçtiğinde "benim bankam" } \\
\text { şeklinde tanım kullanırım }\end{array}$ & 3,20 & 0,717 & & & \\
\hline & Çevremdekileri kullandığım bankaya yönlendirmek için teşvik ederim & 3,07 & 0,702 & & & \\
\hline & Kullandığım bankanın eleştirilmesi hoşuma gitmez. & 2,93 & 0,688 & & & \\
\hline & Başka insanların kullandığım bankayı övmesi beni mutlu eder & 3,20 & 0,669 & & & \\
\hline & Kullandığım banka ile ilgili diğer insanların fikirleri beni çok ilgilendirir & 2,97 & 0,644 & & & \\
\hline \multirow{6}{*}{ 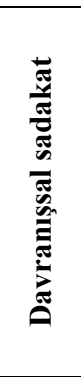 } & $\begin{array}{l}\text { Herhangi bir hizmete ihtiyacım olduğunda ilk tercihim kesinlikle daha } \\
\text { önce hizmet aldığım banka olur. }\end{array}$ & 3,53 & 0,874 & \multirow{6}{*}{9,581} & \multirow{6}{*}{1,437} & \multirow{6}{*}{0,950} \\
\hline & $\begin{array}{l}\text { Bir banka ile ilgili seçim yaptıktan sonra genellikle daha önce hizmet } \\
\text { aldığım bankaya yönelmeyi tercih ederim }\end{array}$ & 3,53 & 0,865 & & & \\
\hline & $\begin{array}{l}\text { Yeni bir hizmete ihtiyaç duyduğumda genellikle daha önce hizmet } \\
\text { aldığım bankayı tercih ederim. }\end{array}$ & 3,57 & 0,850 & & & \\
\hline & Kullandığım bankanın sabit müşterisi olmayı severim & 3,35 & 0,798 & & & \\
\hline & Kullandığım bankayı yakın çevremdeki insanlara öneririm. & 3,37 & 0,767 & & & \\
\hline & $\begin{array}{l}\text { Önerimi isteyen çevremdeki insanlara kullandığım bankayı kesinlikle } \\
\text { tavsiye ederim. }\end{array}$ & 3,35 & 0,751 & & & \\
\hline 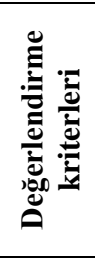 & \multicolumn{6}{|c|}{$\begin{array}{c}\text { Kaiser-Meyer-Olkin Measure of Sampling Adequacy: 0,935 } \\
\text { Approx. Chi-Square: } 6083,400 \\
\text { Barlett's Test of Sphericity: 0,000 } \\
\text { Extraction Method: Principal Components } \\
\text { Rotation Method: Varimax } \\
\text { Aç1klanan Varyans Toplamı: } 0,73 \\
\text { Cronbach's Alpha: } 0,956\end{array}$} \\
\hline
\end{tabular}

\subsection{Korelasyon ve Regresyon Analizi Sonuçları}

$\mathrm{Bu}$ bölümde yapılan faktör analizleri sonucunda algılanan hizmet kalitesi ve müşteri sadakati boyutları aralarındaki ilişkiyi test etmek amaciyla korelasyon ve çoklu doğrusal regresyon analizleri yapılmıştır. Tablo-5 incelendiğinde algılanan hizmet kalitesi ve müşteri sadakati boyutları arasındaki korelasyon analiz sonuçları görülmektedir. Tablo5 incelendiğinde değişkenler arasında genel olarak orta düzeyde anlamll, pozitif ilişkilerin var olduğu görülmektedir. 0.00-0.30 arası değerler düşük düzey ilişkiye ve $0.30-0.70$ arası değerler orta düzey ilişkiye işaret ederken 0.70-1.00 arası değerler yüksek düzey mükemmel ilişkiye işaret etmektedir (Büyüköztürk, 2015:32).

Tablo-5. Korelasyon Analizi Sonuçları

\begin{tabular}{|c|c|c|c|c|c|c|}
\hline Boyutlar & 1. & 2. & 3. & 4. & 5. & 6. \\
\hline 1.Güvenirlilik & 1 & & & & & \\
\hline 2.Empati & ,682* & 1 & & & & \\
\hline $\begin{array}{l}\text { 3.Fiziksel } \\
\text { özellikler }\end{array}$ &, $594 *$ &, $502 *$ & 1 & & & \\
\hline 4.Heveslilik & ,785* & ,626* & ,616* & 1 & & \\
\hline $\begin{array}{r}\text { 5.Bilişsel } \\
\text { sadakat }\end{array}$ &, $569 *$ &, $628 *$ &, $415^{*}$ &, $551 *$ & 1 & \\
\hline $\begin{array}{l}\text { 6.Davranışsal } \\
\text { sadakat }\end{array}$ &, $719 *$ &, $652 *$ &, $580 *$ &, $634 *$ &, $750 *$ & 1 \\
\hline
\end{tabular}

$\mathrm{Bu}$ doğrultuda tablo incelendiğinde güvenirlilik boyutu ile bilişsel sadakat arasında orta düzeyde, davranışsal sadakat ile yüksek düzeyde anlamlı pozitif bir ilişki vardır. Empati boyutu ile bilişsel ve davranışsal sadakat arasında orta düzeyde, anlamlı ve pozitif bir ilişki mevcuttur. Fiziksel görünüm ile bilişsel ve davranışsal sadakat arasında orta düzeyde, anlamlı ve pozitif bir ilişki mevcuttur. Aynı şekilde heveslilik ile bilişsel ve davranışsal sadakat arasında orta düzeyde, anlamlı ve pozitif bir ilişki mevcuttur. Yapılan korelasyon analizi sonucuna göre tüm değişkenler arasında ilişkilerin olduğu görülmektedir.

Bağımsız değişkenlerin bağımlı değişken üzerinde etkisini ölçmek amaciyla çoklu doğrusal regresyon analizleri yapılmıştır. Tablo-6'da algılanan hizmet kalitesi boyutlarının müşteri sadakati boyutlarından davranışsal sadakat üzerine etkileri incelenmiştir. Tablo 6'da algılanan hizmet kalitesi boyutlarından 'güvenirlilik, empati, heveslilik ve fiziksel görünümün müşteri sadakatinin boyutu olan davranışsal sadakat üzerine etkisi ile ilgili sonuçlar yer almaktadır. Tablo-6 incelendiğinde güvenirlilik, empati ve fiziksel görünüm ile bilişsel sadakat arasında orta düzeyde pozitif (sırasıyla; 0,$719 ; 0,652 ; 0,580 ; 0,634)$ korelasyonlar olduğu görülmektedir. VIF değerleri arasında 10'dan yüksek bir değer ve tolerans değerleri arasında 0.20 'den daha düşük bir değer olmadığı için bağımsız değişkenler arasında çoklu bağlantılılığın olmadığı söylenebilir. Ayrıca Durbin-Watson katsayısı $(1,848)$ bağımsız değişkenler ile hata terimleri arasında sorunlu bir ilişkinin olmadığını göstermektedir. Diğer taraftan algılanan hizmet kalitesi alt boyutları (güvenirlilik, empati, heveslilik ve fiziksel görünüm), 
davranışsal sadakat ile orta düzeyde ve anlamlı bir ilişki vermektedir ( $R$ : 0,768, $\mathrm{R}^{2}$ : 0,591, p: 0,000). Standardize edilmiş regresyon katsayılarına $(\beta)$ göre, algılanan hizmet kalitesi alt boyutlarının davranışsal sadakat üzerindeki göreli önem sırası; güvenirlilik, empati, fiziksel görünüm ve heveslilik şeklindedir. Regresyon katsayılarının anlamlılığına ilişkin t-testi sonuçları incelendiğinde ise, güvenirliliğin, empatinin ve fiziksel görünümün davranışsal sadakat üzerinde anlamlı bir etkisinin olduğu görülmektedir. Bu bulgular ışığında; $\boldsymbol{H}_{\boldsymbol{l} \boldsymbol{a}, \boldsymbol{d}, \boldsymbol{j}}$ hipotezleri kabul edilmiştir.

Tablo.6 Algılanan Hizmet Kalitesi Boyutları ve Davranışsal Sadakat Çoklu Doğrusal Regresyon Analiz Sonuçlar

\begin{tabular}{|c|c|c|c|c|c|c|c|c|c|}
\hline Değişkenler & B & $\begin{array}{l}\text { Std. } \\
\text { Hatab }\end{array}$ & $\boldsymbol{\beta}$ & $\mathbf{t}$ & $\mathbf{p}$ & İkili r & Kismi $\mathbf{r}$ & Tol. & VIF \\
\hline Sabit & 477 & ,142 & & 3,360 & ,001 & & & & \\
\hline Güvenilirlik & ,388 & 058 & ,395 & 6,747 &, 000 & ,719 & ,327 & ,262 & 3,816 \\
\hline Empati & ,241 &, 043 & ,259 & 5,619 &, 000 & ,652 & ,277 &, 509 & 1,964 \\
\hline Fiziksel görünüm & ,195 &, 045 & ,186 & 4,301 &, 000 & ,580 & 216 & ,296 & 3,380 \\
\hline Heveslilik &, 047 & 056 & 047 & ,831 & ,406 & ,634 & 043 & ,608 & 1,646 \\
\hline \multicolumn{10}{|c|}{ Bağımlı değișken: Davranışsal sadakat } \\
\hline
\end{tabular}

Tablo 7. Algılanan Hizmet Kalitesi Boyutları ve Bilişsel Sadakat İçin Çoklu Doğrusal Regresyon Analiz Sonuçları

\begin{tabular}{llllllllll}
\hline Değişkenler & $\mathbf{B}$ & Sd. Hataв & $\boldsymbol{\beta}$ & $\mathbf{t}$ & $\mathbf{p}$ & İkili $\mathbf{r}$ & Kismi r & Tol. & VIF \\
\hline Sabit &, 622 &, 160 & & 3,876 &, 000 & & & & \\
\hline Güvenilirlik &, 136 &, 065 &, 143 & 2,092 & $\mathbf{, 0 3 7}$ &, 569 &, 107 & $\mathbf{2 6 2}$ & $\mathbf{3 , 8 1 6}$ \\
\hline Empati &, 375 &, 048 &, 417 & 7,749 & $\mathbf{, 0 0 0}$ &, 628 &, 370 & $\mathbf{, 5 0 9}$ & $\mathbf{1 , 9 6 4}$ \\
\hline Fiziksel görünüm &, 017 &, 051 &, 017 &, 331 &, 741 &, 415 &, 017 &, $\mathbf{2 9 6}$ & $\mathbf{3 , 3 8 0}$ \\
\hline Heveslilik &, 163 &, 064 &, 168 & 2,556 & $\mathbf{, 0 1 1}$ &, 551 &, 130 & $\mathbf{, 6 0 8}$ & $\mathbf{1 , 6 4 6}$ \\
\hline
\end{tabular}

Bağımlı değişken: Bilişsel sadakat

$\begin{array}{lllll}R: 0,666 & R^{2:} 0,443 & F_{(4,379)}: 75,362 & \text { p: } 0,000 & \text { Durbin-Watson:1,680 }\end{array}$

Tablo 7'de ise algilanan hizmet kalitesi boyutlarından güvenirlilik, empati, heveslilik ve fiziksel görünümün müşteri sadakati boyutu olan "bilişsel sadakat" üzerine etkisi ile ilgili sonuçlar yer almaktadır. Tablo 7 incelendiğinde, güvenirlilik, empati, heveslilik ve fiziksel görünüm ile bilişsel sadakat arasında orta seviyede pozitif (sırasıyla; $0,569 ; 0,628 ; 0,415 ; 0,551)$ bir ikili korelasyon olduğu görülmektedir. VIF değerleri arasında 10'dan yüksek bir değer ve tolerance değerleri arasında 0.20 'den daha düşük bir değer olmadığı için bağımsız değişkenler arasında çoklu bağlantılıların olmadığı söylenebilir. Ayrıca Durbin-Watson katsayısı $(1,680)$ bağımsız değişkenler ile hata terimleri arasında sorunlu bir ilişkinin olmadığını göstermektedir. Diğer taraftan algılanan hizmet kalitesi alt boyutları (güvenirlilik, empati, fiziksel görünüm ve heveslilik), bilişsel sadakat ile orta düzeyde ve anlamlı bir ilişki vermektedir (R: 0,666, R2: 0,443, p: 0,000). Standardize edilmiş regresyon katsayılarına $(\beta)$ göre, algılanan hizmet kalitesi alt boyutlarının bilişsel sadakat üzerindeki göreli önem sırası; empati, heveslilik, güvenirlilik ve fiziksel görünüm şeklindedir. Regresyon katsayılarının anlamlılığına ilişkin t-testi sonuçları incelendiğinde ise, empati, heveslilik ve güvenirliliğin bilişsel sadakat üzerinde anlamlı bir etkisinin olduğu görülmektedir. Bu bulgular 1şı̆̆ında $\boldsymbol{H}_{l f, i, l}$ hipotezleri kabul edilmiştir.

\subsection{Farklılık Analizlerine İlişkin Bulgular}

$\mathrm{Bu}$ bölümde katılımcıların demografik özellikleri ile algıladıkları banka hizmet kalitesi ve müşteri sadakatine yönelik düşünceleri arasında anlamlı farklılıkların olup olmadığı incelenmiştir. 
Tablo 8. Müşterilerin Cinsiyetlerine Göre T-Testi Sonuçları

\begin{tabular}{|c|c|c|c|c|c|c|c|}
\hline Faktörler & Cinsiyet & $\mathrm{n}$ & $\mathrm{X}$ & $\mathrm{Sd}$ & $\mathrm{t}$ & $\mathrm{p}$ & Anlamlı Farkl1lık \\
\hline \multirow{2}{*}{ Güvenirlilik } & Kadın & 197 & 3,7024 & 986 & 3,146 & $0,002 *$ & \multirow{2}{*}{ Kadın-Erkek } \\
\hline & Erkek & 187 & 3,3663 & 1,10 & 3,137 & $0,002 *$ & \\
\hline \multirow{2}{*}{ Empati } & Kadın & 197 & 3,2406 & 1,09 & 2,288 & $0,023^{*}$ & \multirow{2}{*}{ Kadın-Erkek } \\
\hline & Erkek & 187 & 2,9743 & 1,18 & 2,283 & $0,023^{*}$ & \\
\hline \multirow{2}{*}{ Heveslilik } & Kadın & 197 & 3,6497 & 994 & 2,768 & $0,006^{*}$ & \multirow{2}{*}{ Kadın-Erkek } \\
\hline & Erkek & 187 & 3,3519 & 1,11 & 2,760 & $0,006^{*}$ & \\
\hline \multirow{2}{*}{ Bilişsel sadakat } & Kadın & 197 & 3,0350 & 971 & 2,630 & $0,009 *$ & \multirow{2}{*}{ Kadın-Erkek } \\
\hline & Erkek & 187 & 2,7605 & 1,07 & 2,623 & $0,009 *$ & \\
\hline \multirow{2}{*}{$\begin{array}{l}\text { Davranışsal } \\
\text { sadakat }\end{array}$} & Kadın & 197 & 3,6015 & 1,01 & 2,345 & $0,020^{*}$ & \multirow{2}{*}{ Kadın-Erkek } \\
\hline & Erkek & 187 & 3,3485 & 1,103 & 2,339 & $0,020^{*}$ & \\
\hline
\end{tabular}

Bu doğrultuda ilişkisiz örneklemler için tek faktörlü varyans analizi (One-Way Anova) tekniği ve ilişkisiz (bağımsız) örneklemeler T-Testi (Independent Samples T-Test) teknikleri kullanılmıştır. Katılımcıların cinsiyetlerine göre yapılan T-testi analiz sonuçları tablo-8'degörülmektedir. Tablo-8 incelendiğinde cinsiyete göre katılımcıların hizmet kalitesi algıları ve müşteri sadakat algıları arasında anlamlı farklılıkların olduğu görülmektedir. Güvenirlilik, empati, heveslilik, bilişsel sadakat ve davranışsal sadakat boyutlarının tümünde kadınların erkeklere göre daha olumlu bir algı içerisinde oldukları görülmektedir. Katılımcıların medeni durumlarına göre yapılan T-testi analiz sonuçları tablo-9'da görülmektedir. Tablo-9 incelendiğinde medeni duruma göre katılımcıların hizmet kalitesi algıları ve müşteri sadakat algıları arasında anlamlı farklılıkların olduğu görülmektedir. Güvenirlilik, heveslilik ve bilişsel sadakat boyutunda bekarların evlilere göre; empati boyutunda evlilerin bekarlara göre daha olumlu bir alg1 içerisinde oldukları görülmektedir.

Tablo 9. Müşterilerin Medeni durumuna Göre T-Testi sonuçları

\begin{tabular}{|c|c|c|c|c|c|c|c|}
\hline Faktörler & $\begin{array}{l}\text { Medeni } \\
\text { durum }\end{array}$ & $\mathrm{N}$ & $\mathrm{X}$ & $\mathrm{Sd}$ & $\mathrm{t}$ & $\mathrm{p}$ & $\begin{array}{l}\text { Anlamlı } \\
\text { Farklılık }\end{array}$ \\
\hline \multirow{2}{*}{ Güvenirlilik } & Evli & 189 & 3,3962 & 1,06 & $-2,618$ & $0,009 *$ & \multirow{2}{*}{ Evli-Bekâr } \\
\hline & Bekâr & 195 & 3,6769 & 1,03 & $-2,617$ & $0,009^{*}$ & \\
\hline \multirow{2}{*}{ Empati } & Evli & 189 & 3,9492 & 1,12 & $-2,745$ & $0,006^{*}$ & \multirow{2}{*}{ Evli-Bekâr } \\
\hline & Bekâr & 195 & 3,2677 & 1,14 & $-2,746$ & $0,006^{*}$ & \\
\hline \multirow{2}{*}{ Heveslilik } & Evli & 189 & 3,3820 & 1,03 & $-2,238$ & ,0026* & \multirow{2}{*}{ Evli-Bekâr } \\
\hline & Bekâr & 195 & 3,6236 & 1,07 & $-2,239$ &, $0026 *$ & \\
\hline \multirow{2}{*}{ Bilişsel sadakat } & Evli & 189 & 3,7360 & 1,02 & $-3,131$ & $0,002 *$ & \multirow{2}{*}{ Evli-Bekâr } \\
\hline & Bekâr & 195 & 2,0615 & 1,01 & $-3,131$ & $0,002 *$ & \\
\hline
\end{tabular}

Katılımcıların eğitim durumlarına göre yapılan ANOVA analiz sonuçları tablo-10'da görülmektedir. Tablo 10 incelendiğinde katılımcıların eğitim ve yaş durumlarına göre One-Way Anova testi bulgularında; güvenirlilik, fiziksel görünüm, heveslilik ve davranışsal sadakat boyutlarında anlamlı farklılıklar olduğu belirlenmiştir. Gruplar arası farkların tespiti için Tukey testi uygulanmıştır. Genel olarak eğitim düzeyi lisansüstü olanların, lise, ön lisans ve lisans düzeyinde olanlara göre hizmet kalitesini daha olumlu algıladıkları görülmektedir. Müşteri sadakati değişkeninde ise yine lisansüstü eğitim düzeyinde olanların ön lisans eğitim düzeyinde olanlara göre daha olumlu bir alg1 içerisinde oldukları görülmektedir.

Katılımcıların yaş gruplarına göre müşteri sadakat boyutunda farklılık olduğu görülmektedir. Bilişsel sadakat boyutunda da 46 yaş ve üzeri grubun, $18-24$ ve 25-31 yaş gurubuna göre daha olumlu bir alg1 içerisinde oldukları görülmektedir. Yani ileri yaş grubunun mutlak sadakat düzeyinin daha yüksek olduğu söylenebilir. 
Tablo 10. Müşterilerin Eğitim Durumları göre ANOVA Analizi Sonuçları

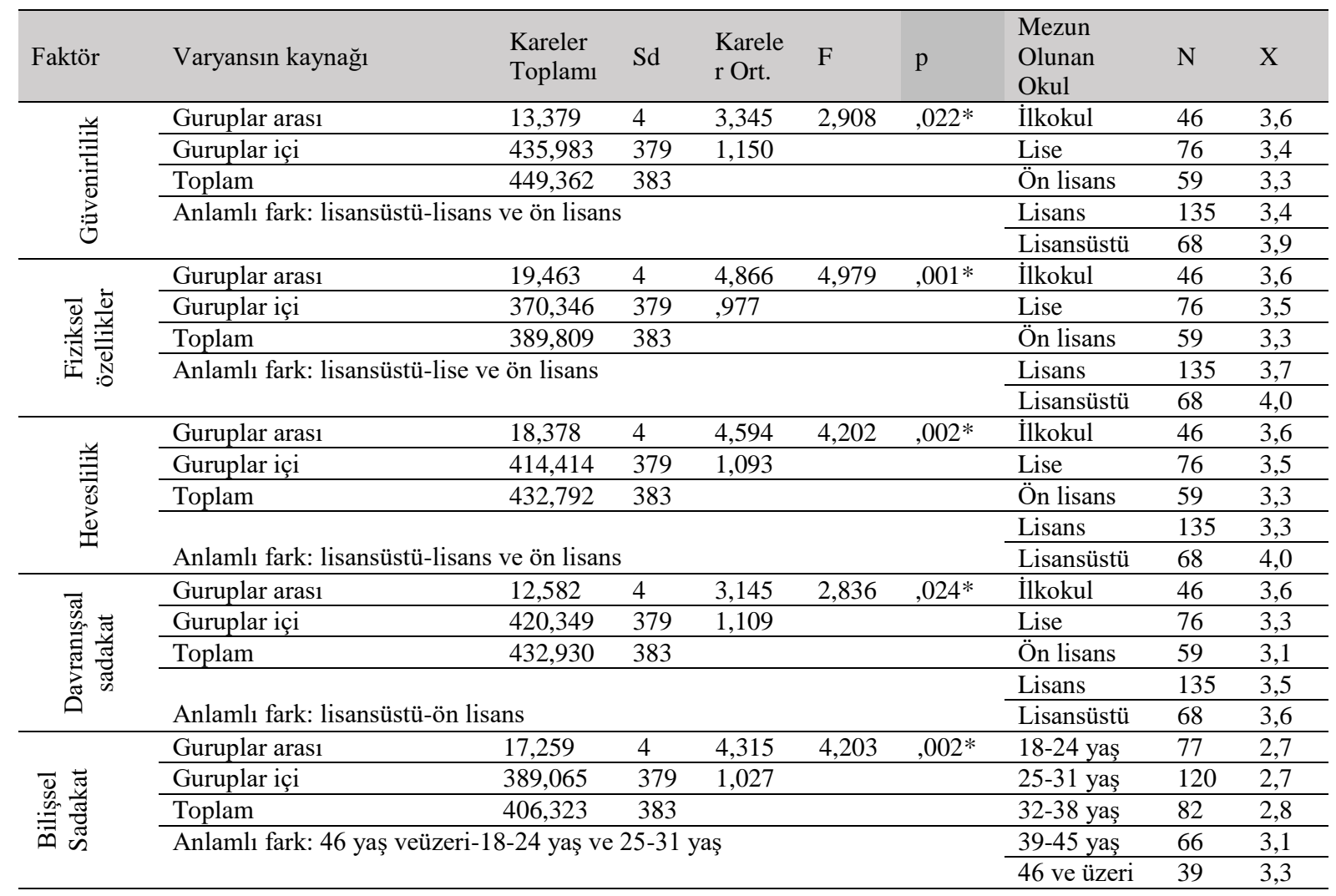

\section{Sonuç ve Öneriler}

Rekabetin giderek yoğunlaştığı günümüz dünyasında sadık müşteriler üzerine stratejiler geliştirmek yeni müşteri elde etmekten daha önemli ve daha tasarruflu hale gelmiştir. İşletmeler müşteri ilişkileri yönetimine giderek daha fazla önem vermeye başlamışlardır. Hatta işletmeler de müşteri deneyimi departmanlarının kurulması müşteri sadakatine ne kadar önem verildiğini gözler önüne sermektedir. Bu doğrultuda müşteri sadakatini etkileyen faktörlerin belirlenmesi, araştırılması önem arz etmektedir. Bankaların da etkin bir şekilde hizmet sunabilmeleri, hizmet kalitelerini arttırmaları müşteri sadakati oluşturmaları açısından önemlidir. Yapılan bu araştırma da bireysel banka müşterilerinin hizmet aldıkları bankalardan algıladıkları hizmet kalitelerinin müşteri sadakati üzerine etkisini belirlemek amaçlanmıştır. Araştırmadaki önem müşterilerin işletmelerde uzun dönemli kalmalarının işletmelere sağlayacağı faydadır. Bu amaçla Düzce'de faaliyet de bulunan kamu ve özel tüm bankaların hizmet kaliteleri, bankaların bireysel müşterileri tarafindan değerlendirilmiştir. Çalışmada belirlenen amaçlar doğrultusunda öncelikle değişkenlerin yapılarını ve güvenilirliklerini tespit etmek amacıyla faktör ve güvenilirlik analizleri gerçekleştirilmiştir. Daha sonrasında ise korelasyon ve çoklu doğrusal regresyon ve farklılık analizleri gerçekleştirilmiştir. Yapılan faktör analizi sonuçlarına göre; banka hizmet kalitesi ölçeğinde 4 farklı boyut ortaya çıkmıştır. Bu araştırmada kullanılan SERPERF ölçeğinde 5 faktör bulunmasına rağmen analiz sonucunda ortaya 4 faktör çıkmasında, ölçeğin uygulanan bölgede müşteri davranışlarının farklı olması, evren ve örneklemin farklı olması, tüketicilerin anket sorularını farklı algılamaları gibi nedenler gösterilebilir. $\mathrm{Bu}$ araştırmada ortaya çıkan sonuç, banka hizmet kalitesi faktörlerinden güven ve güvenilirlik faktörünün tek faktör içerisinde toplandığıdır. Bu boyutlar içerisinde banka hizmet kalitesini en iyi düzeyde temsil eden boyut güvenilirlik boyutudur. $\mathrm{Bu}$ boyutu sırasıyla empati, isteklilik ve fiziksel görünüm boyutu takip etmektedir.

Literatürde SERVQUAL ve SERVPERF ölçeği kullanılarak yapılan benzer çalışmalarda da faktör isimleri ve sayıları aynı veya farklı çıktığı görülmektedir. Çatı ve Öcel'in (2015) aynı ölçeği kullanarak farklı alanda yaptığı çalışmalarında güven ve güvenirlilik faktörlerinin aynı şekilde bir faktör altında toplandığı görülmektedir. Öncü vd. (2010), hizmet kalitesinin ölçülmesi ve bankacılık sektöründeki uygulama isimli çalışmalarında, hizmet kalitesini etkileyen değişkenlere yönelik yapılan faktör analizi sonucunda, yine 4 boyut ortaya çıktığı tespit edilmiştir. Bu boyutların önem sıraları, fiziki unsurlar, yeterlilik, güvenilirlik ve empati olarak sıralanmıştır. Çiftçi'nin (2006), hizmet kalitesi ve bankacılık sektöründe hizmet kalitesinin ölçülmesi adlı çalışmasında, faktör sayısını 5 olarak bulmuştur ve faktörlerin önem dereceleri: güvenirlilik, heveslilik, güvence empati ve fiziksel özellikler olarak değişiklik gösterdikleri görülmüştür.

Müşteri sadakati ölçeğinde 2 farklı boyut ortaya çıkmıştır. $\mathrm{Bu}$ boyutlar: davranışsal sadakat ve bilişsel sadakattir. Ölçeğin alındığı çalışma (Gümüşbuğa, 2015) incelendiğinde müşteri sadakatinin bilişsel sadakat, davranışsal sadakat ve tutumsal sadakate yönelik üç faktör olduğu anlaşılmaktadır. Fakat bu çalışmada bilişsel sadakat ve tutumsal sadakat ifadelerinin aynı faktör altında toplandığı gözlemlenmektedir. Evrenin farklı olması böyle bir sonucu ortaya çıkardığı düşünülmektedir. 
Algılanan hizmet kalitesi ve müşteri sadakati değişkenleri arasındaki korelasyon analiz sonuçlarına göre; en yüksek ilişki, davranışsal sadakat ile güvenirlilik arasında iken, en düşük ilişki, fiziksel görünüm ile bilişsel sadakat arasındadır. Bu sonuçla Tüfekçi ve Tüfekçi'nin (2006), Çiftçi’nin (2006), Ustasüleyman ve Eyüboğlu'nun (2010), Onan'ın (2017) çalışmaları benzerlik göstermektedir.

Yapılan çoklu doğrusal regresyon analiz sonuçlarına göre algılanan hizmet kalitesi boyutlarından güvenirlilik, empati ve fiziksel görünümün, müşteri sadakati boyutlarından davranışsal sadakati etkilediği ortaya çıkmıştır. Bu doğrultu da algilanan hizmet kalitesinin ölçeğinde yer alan güvenirlilik ilgili ifadeler düşünüldüğünde; banka çalışanlarının müşterilerine verdikleri sözleri zamanında yerine getirmeleri ve kayıtlarını hatasız tutmaları davranışsal sadakati pozitif yönde etkilemektedir. Empati ile ilgili ifadeler düşünüldüğünde; banka çalışanlarının her bir müşteriyle tek tek özel olarak ilgilenmeleri ve müşterilerinin çıkarlarını her şeyin üstünde tutmaları davranışsal sadakat duygusunu pozitif yönde etkilemektedir. Bir diğer önemli boyut olan fiziksel görünüm faktöründe ise banka çalışanlarının temiz ve düzgün görünüşlerinin olması ve hizmet binalarının modern görünüşlü göze hoş görünür olması davranışsal sadakati pozitif yönde etkilemektedir denilebilir.

Algılanan hizmet kalitesi boyutlarından güvenirlilik, empati ve hevesliliğin müşteri sadakati boyutlarından bilişsel sadakati etkilediği ortaya çıkmıştır. Algılanan hizmet kalitesinin ölçeğinde yer alan empati ile ilgili ifadeler düşünüldüğünde; banka çalışanlarının her bir müşteriyle tek tek özel olarak ilgilenmeleri ve müşterilerinin çıkarlarını her şeyin üstünde tutmaları bilişsel sadakat duygusunu pozitif yönde etkilemektedir. İkinci önemli boyut olan heveslilik faktöründe ise banka çalışanlarının müşterilere yardım etmeye her zaman istekli ve gönüllü olmaları ve hizmetleri mümkün olan en kısa sürede vermeleri bilișsel sadakat duygusunu pozitif yönde etkilemektedir.

Araştırmadan çıkan sonuçlar neticesinde bankalara şu önerilerde bulunulabilir: Analizler sonucunda bireysel banka müşterilerin algıladığı en önemli faktörün güvenirlilik olduğu bulunmuştur. Güvenilirlik boyutu içerisinde güven ile ilgili ifadeler de yer almaktadır. Ankette geçen ifadeler irdelendiğinde verilen sözlerin yerine getirilmesi büyük önem arz etmektedir. Kayıt ve faturalama işlemleri yapılırken, internet bankacılığını kullanılırken, bankamatikler kullanılırken, mobil bankacılık kullanılırken, müşterilerin bilgilerine ve mahremiyetine özen gösterilmelidir. Bir diğer önemli faktör empatidir. Banka personelleri gerek şubelerde gerekse çağrı merkezlerinde müşterilerine karşı her zaman saygılı, nazik ve yardımsever olmalılardır. Müşteriler bankalardan kendileriyle özel ve kişisel olarak ilgilenmelerini önemsemektedirler. $\mathrm{Bu}$ yüzden, bankalar müşterilerin her birine ayrıcalıklı olduğu duygusunu hissettirmelilerdir. Belki onların özel ihtiyaçları ile alakadar olabilirler. Heveslilik faktöründe de bankaların işlerini, her zaman, her koşulda istekle ve süratle yapmalarını bekleyen müşterileri olduğunu bilmeleri gerekir. Bankada işlem yaptırmak için dakikalarca bekleyen müşteri sıralarına çözüm üretmeleri ve hizmet hızlarını geliştirmeleri gerekir. Bir bankanın fiziksel özelliklerinde hizmet kalitesi ise, bankalar son teknolojiye uygun çağdaş araç ve gereçlere sahip olarak, hizmet verilen ortamda tertip ve düzeni sağlayarak iyi bir izlenim oluşturabilir. Özellikle müşterilerin algı eşiklerini geçebilmek adına işletme içerisindeki dekarosyon belli aralıklarla değiştirilebilir. Müşteriye güven veren mavi ve yeşil tonlar kullanılabilir. Bütün bunlar, bankaların ileride müşteriyi tutma ve müşteri sadakati oluşturma noktasında hizmet kalitelerini gözden geçirmeleri açısından önemli bir çalışma olabilir.

Sonuç olarak; bu çalışma, SERPERF ölçümü ile bireysel banka müşterilerinin algılamış oldukları hizmet kalitesinin müşteri sadakatini ölçme konusunda yol göstermektedir. Sonraki çalışmalarda algılanan risk kavramı da dikkate alınabilir. Algılanan hizmetin müşteri sadakatine etkisinde ağızdan ağıza iletişimin aracı etkisi araştırılabilir. Örneklem için yalnızca Düzce ilinde faaliyet gösteren özel ve kamu bankalarının bireysel banka müşterilerinin ele alınması çalışmanın sınırlılığıdır. Bundan sonraki çalışmalarda tek bir bankanın müşteri kitlesinden yola çıkılarak, bireysel, ticari ve dijital müşteriler ayrı ayrı ele alınıp bankaya dair daha detaylı sonuçlara ulaşılabilir.

\section{Kaynakça}

Altıntaş, M. H. (2000) Tüketici Davranışları. Bursa: Alfa.

Arabacı, H. (2018).Türkiye' de Bankacılık Sektörünün Gelişimi, Meriç Uluslararası Sosyal ve Stratejik Araştırmalar Dergisi, Cilt: 2, Sayı: 3, Y1l: 2018, Sayfa: 25-42.

Aydın, K.,Yıldırım S.,(2012).Hizmet Sektöründe Servperf Ölçeği ile Hizmet Kalitesinin Belirlenmesi (Sağlık Hizmetleri Sektöründe Bir Uygulama, Ekonomi ve Yönetim Araştırmaları Dergisi, Cilt:1 Sayı: 2

Bayruk, N. ve Küçük, F. (2007). Müşteri Tatmini ve Müşteri Sadakati İlişkisi Marmara Üniversitesi İktisadi ve İdari Bilimler Fakültesi Dergisi, Cilt: XXII, Sayı: 1.

Bülbül, H., Akın, M., Demirer, Ö. \& Doğan, İ.C. (2012). Türk Bankacılık Sektöründe Hizmet Kalitesinin Müşteri Tatmini ve Tekrar Satın Alma Niyeti Üzerine Etkisi: Yapısal Eşitlik Modeli İle Bir İnceleme. Doğuş Üniversitesi Dergisi, 13(1), 28-40.

Büyüköztürk, Ş. (2010). Sosyal Bilimler için Veri Analizi El Kitabı, Pegem Akademi Yayıncılık, Ankara.

Cronin, J. Joseph Jr, and Taylor, Steven A. (1992), "Measuring Services Quality", Journal of Marketing, Vol 56, No 3, s. 55-68.

Çatı, K.ve Öcel, Y. (2015). Toplumda Algılanan Doktor İmajının Sağlık Hizmet Kalitesi Üzerine Etkisi, Düzce Üniversitesi Sosyal Bilimler Enstitüsü Dergisi, Sayı: 2.

Çiftçi, A. G. (2006). Hizmet Kalitesi ve Bankacılık Sektöründe Hizmet Kalitesi Ölçümüne Yönelik Bir Uygulama. Dokuz Eylül Üniversitesi.

Değermen, H.A. (2006): Hizmet Ürünlerinde Kalite, Müşteri Tatmini ve Müşteri Sadakati, Türkmen Kitabevi, İstanbul.

Demirören, P.(2009): "Türk Bankacılık Sektöründe Müşteri İlişkileri Yönetimi Uygulamalarının Müşteri Tatmini 
ve Müșteri Sadakatine Etkileri," Basılmamıș Yüksek Lisans Tezi, Niğde Üniversitesi Sosyal Bilimler Enstitüsü, Niğde.

Dick, A., Basu, K., (1994). Customer loyalty: toward an integrated conceptual framework. Journal of the Academy of Marketing Science 22 (2), 99-113.

Gümüşbuğa, F. (2015): Bankacılıkta Müşteri İlişkileri Yönetiminin Müșteri Sadakatine Etkisi, Karabük Üniversitesi, Uluslararası İşletme ve Yönetim Dergisi C.:3 S.:1 Y1l:2015, ss. 123-153.

Işık, O. ,Akbolat, M. \& Ünğan, C.(2013): Kamu ve Özel Banka Müşterilerinin Hizmet Kalite Algılarının Değerlendirilmesi: Bir Alan Araştırması, İşletme Bilimi Dergisi, Cilt:1 Say1:2.

Juran, Joseph.M. Frank. M. Gryna (1988) Juran’s Quality Control Handbook, McGraw Hill Co., 4. Basım.

Karamustafa, K., \& Yıldırım, M. (2007). Tüketicilerin Bireysel Banka Tercihine İlişkin Kayseri İlinde Yapılan Bir Araştırma. Ekonomik ve Sosyal Araştırmalar Dergisi.

Kaytanc1, B.G., Ergeç, E.H., Toprak, M. (2013).Katılım Bankası Müșterilerinde Bankacılık Ürün ve Hizmetlerine Yönelik Memnuniyet: Türkiye Örneği. International Conference on Eurasian Economies, 801-811.

Koçer, Köksal.,(2017) Müşteri İlişkileri Yönetiminin Müşteri Sadakati Üzerine Etkisi, Sosyal Bilimler Enstitüsü Dergisi, cilt: 7 sayı:2.

McGoldrick, P.J., ve Andre E, (1997), "Consumer misbehaviour Promiscuity orLoyalty in Grocery Shopping", Journal of Retailing and Consumer Services, Vol. 4,No. 2, ss. 73-81.

Mucuk, İ. (1994). Pazarlama İlkeleri. DER Yayınları 6. Bask1, İstanbul.

Onan, G.,(2017) . Bankacılık Sektöründe Hizmet Kalitesinin Marka Bağlılığı Üzerine Etkisi, Ordu Üniversitesi Sosyal Bilimler Araştırmaları Dergisi, 7(3), 529-538.

Oyman, M. (2002); "Müşteri Sadakati Sağlamada Sadakat Programlarının Önemi", Kurgu Dergisi, sayı 19.

Öncü, M, Kutukız，D，Koçoğlu， C. (2010). Hizmet Kalitesinin Ölçülmesi ve Bankacılık Sektöründe Bir Uygulama. Muhasebe ve Finansman Dergisi, (45), 237-252.

Özer, Ö. ve Günaydın, Y. (2010) "Otel İşletmelerinde Müşteri Memnuniyeti ve Müşteri Sadakati İlişkisi: Dört Yıldızlı Otel İşletmelerinde Bir Uygulama, "İşletme Fakültesi Dergisi, 11 (2), 127-154.
Parasuraman, A., V. Zeithaml, and L.L. Berry (1988), "SERVQUAL: A Multiple Item Scale for Measuring Customer Perceptions of Service Quality," Journal of Retailing, 64 (1), pp.12-37.

Sütütemiz, N., Çiftyıldız, S .(2014). "Müşteri Sadakati Modellerinin Karşılaştırılması Üzerine Bir Çalışma". Akademik İncelemeler Dergisi (AID) : 155-172.

Tosun, N. B. (2014). Marka Yönetimi, Beta Basım Yayım Dağıtım, 2. Baskı, İstanbul.

Tüfekci, N., Tüfekci, K.,(2006). Bankacılık Sektöründe Farklı Olma Üstünlüğünün ve Müşteri Sadakatinin Yarattığ1 Değer: Isparta ilinde Bir Uygulama, Süleyman Demirel Üniversitesi Sosyal Bilimler Enstitüsü Dergisi, sayı:4, 170,183.

Türkiye Bankalar Birliği, http://www.tbb.org.tr

Ustasüleyman, T., \& Eyüboglu, K. (2010). Bireylerin İnternet Bankacılığını Benimsemesini Etkileyen Faktörlerin Yapısal Eşitlik Modeli ile Belirlenmesi. Journal of BRSA Banking \& Financial Markets, 4(2).

Üzerem, N. (1997). "Hizmet Kalitesinin Yönetimi” Pazarlama Dünyası Dergisi,11(62), ss: 34-41.

Yıldırım, Ö. (2005). Termal Turizm İşletmelerinde Müşteri Sadakati ve Bir Araştırma, Balıkesir Üniversitesi Sosyal Bilimler Enstitüsü Turizm İşletmeciliği ve Otelcilik Ana Bilim Dalı, Yüksek Lisans Tezi, Balıkesir.

Yıldız, S. ve Çilingir, Z. (2010). Elektronik Pazarlamada Müşteri Sadakatinin Geliştirilmesi: Karadeniz Teknik Üniversitesi Öğrencileri Üzerine Bir Araştırma. Çukurova Üniversitesi Sosyal Bilimler Enstitüsü Dergisi. Cilt: 19, Say1: 1, ss: 412-428.

Yılmaz, V., Filiz, Z. \& Yaprak, B. (2007). Servqual Yöntemiyle Yükseköğretimde Hizmet Kalitesinin Ölçülmesi. Anadolu Üniversitesi Sosyal Bilimler Dergisi, 7(1), 299-316.

Yılmaz, V., Celik, H.E. \& Depren B.(2007). Devlet ve Özel Sektör Bankalardaki Hizmet Kalitesinin Karşılaştırılması, Doğuş Üniversitesi Dergisi,8 (2) 2007,234-248.

Yücel, M., (2013) Toplam Hizmet Kalitesinin Serqual Analizi İle Ölçümü: Bankacılık Sektöründe Bir Araştırma: Elektronik Sosyal Bilimler Dergisi, Cilt:12 Sayı: 44 (082-106)

Zeithaml, Valarie A., Parasuraman, A, ve Berry, Leonard L. (1990). Delivering Quality Service: Balancing Customer Perceptions and Expectations, The Free Press, New York. 